\title{
PERAN BRAND IMAGE MEMEDIASI SOCIAL MEDIA MARKETING TERHADAP KEPUTUSAN PEMBELIAN
}

\section{Kompyang Gede Sathya Narayana ${ }^{1}$ Gede Bayu Rahanatha ${ }^{2}$}

\author{
${ }^{1,2}$ Fakultas Ekonomi dan Bisnis Universitas Udayana, Bali, Indonesia \\ email: gedesathya555@gmail.com
}

\begin{abstract}
ABSTRAK
Tujuan penelitian ini adalah untuk mengetahui peran brand image memediasi pengaruh social media marketing terhadap keputusan pembelian pada konsumen Denara Bali. Penelitian ini dilakukan di Kota Denpasar dengan menggunakan sampel sebanyak 120 responden yang sudah pernah membeli produk Denara Bali dan sudah follow dan pernah berkomunikasi dengan admin Instagram @ denarabaliofficial, dengan teknik non probability sampling dengan metode purposive sampling. Pengumpulan data dilakukan melalui penyebaran kuesioner. Teknik analisis yang digunakan pada penelitian ini adalah analisis jalur (path analysis) dan uji sobel. Hasil penelitian ini menemukan bahwa social media marketing berpengaruh positif dan signifikan terhadap brand image. Social media marketing berpengaruh positif dan signifikan terhadap keputusan pembelian. Brand image berpengaruh positif dan signifikan terhadap keputusan pembelian. Brand image merupakan variabel mediasi pengaruh antara social media marketing terhadap keputusan pembelian pada konsumen Denara Bali di Kota Denpasar.

Kata kunci : social media marketing, brand image, keputusan pembelian.
\end{abstract}

\begin{abstract}
The purpose of this study was to determine the role of brand image mediating the effect of social media marketing on purchasing decisions on Denara Bali consumers. This research was conducted in Denpasar City by using a sample of 120 respondents who had already purchased Denara Bali products and had followed and had communicated with Instagram @ denarabaliofficial admin, with non-probability sampling techniques with purposive sampling method. Data collection was carried out through questionnaires. The analysis technique used in this research is path analysis and sobel test. The results of this study found that social media marketing had a positive and significant effect on brand image. Social media marketing has a positive and significant influence on purchasing decisions. Brand image has a positive and significant influence on purchasing decisions. Brand image is a mediating variable of the influence between social media marketing on purchasing decisions on Denara Bali consumers in Denpasar City.

Keywords: social media marketing, brand image, purchasing decisions
\end{abstract}




\section{PENDAHULUAN}

Perkembangan era saat ini dimana teknologi menjadi semakin canggih telah mendorong terciptanya era digital sehingga menyebabkan manusia memiliki ketergantungan terhadap teknologi salah satunya adalah dengan penggunaan internet. Saat ini internet dapat diakses dengan mudah dimanapun dan kapanpun melalui telepon seluler yang biasa disebut smartphone. Keputusan pembelian di era digital ini terjadi berdasarkan sebagai mana perusahaan sering muncul di smartphone dalam hal ini seperti melihat iklan di Instagram, Facebook, Twitter, karena sekarang konsumen lebih sering melihat smartphonenya dibanding televisi, maka dari itu keputusan pembelian terjadi ketika seseorang secara tidak sengaja melihat iklan di social media, lalu merasa tertarik atau sesuai dengan produk yang dibutuhkannya saat ini.

Kotler \& Armstrong (2008:181) menyatakan bahwa keputusan pembelian konsumen adalah membeli merek yang paling disukai dari berbagai alternatif yang ada. Morissan (2014:111) menyebutkan bahwa keputusan pembelian (purchase decision) adalah tahap lanjutan setelah adanya niat atau keinginan membeli. (Kotler \& Armstrong (2008:224-228) menyebutkan terdapat lima tahap konsumen dalam melakukan keputusan pembelian yaitu pengenalan masalah, pencarian informasi, evaluasi alternatif, keputusan pembelian, dan perilaku setelah membeli.

Fenomena ini tentu mempengaruhi strategi perusahaan dalam memasarkan produknya. Hampir seluruh perusahaan saat ini sudah memanfaatkan pemasaran secara digital karena social media merupakan alat promosi bisnis yang efektif dibandingkan media tradisional karena dapat diakses oleh siapa saja, dan dapat menjangkau pasar yang lebih luas (Kompasiana.com, 2018). Melalui social media, perusahaan dapat menentukan sendiri kearah mana target market yang ingin disasar, seperti kita memasang iklan kita dapat mengatur kearah mana target iklan tersebut, mulai dari jenis kelamin, usia, kesukaan, pekerjaan, sehingga iklan kita dapat tersampaikan kepada karakteristik orang tersebut, dengan adanya digital marketing kita dapat menjangkau lebih luas pasar dengan biaya yang relatif lebih terjangkau dibandingkan dengan media tradisional yang kita tidak dapat menentukan target iklan yang spesifik, serta tentunya biaya yang lebih besar dari media sosial.

\section{Tabel 1. \\ Pertumbuhan Pengguna Sosial Media di Indonesia Tahun 2017-2018}

\begin{tabular}{cccc}
\hline Tahun & Total Populasi (jiwa) & Pengguna Internet (jiwa) & Persentase \\
\hline $\mathbf{2 0 1 7}$ & 262 juta & 143,26 juta & $54,68 \%$ \\
$\mathbf{2 0 1 8}$ & 264,16 juta & 171,17 juta & $64,8 \%$ \\
Peningkatan & $\mathbf{2 , 1 6}$ juta & $\mathbf{2 7 , 9 1}$ juta & $\mathbf{1 0 , 1 2 \%}$ \\
\hline
\end{tabular}

Sumber: Data diolah, 2019

Hasil Survey Peningkatan Pengguna Internet Indonesia Tahun 2017-2018 yang dilakukan oleh APJII (Asosiasi Penyelenggara Jasa Internet Indonesia).

Berdasarkan hasil survey yang dilakukan oleh APJII menunjukan hasil bahwa dari tahun 2017-2018 terdapat peningkatan populasi sebesar 2,16 juta jiwa, diikuti oleh peningkatan signifikan pengguna internet sebesar 27,91 juta jiwa, dengan persentase $10,12 \%$ ini mengindikasikan bahwa penjualan secara online merupakan 
salah satu cara yang wajib diambil oleh perusahaan karena berdasarkan hasil survey tersebut menunjukan akan ada peningkatan jumlah penduduk dan pengguna internet di setiap tahunnya. Berikut merupakan survey alasan utama orang menggunakan internet yang dilakukan oleh APJII pada tahun 2018.

Tabel 2.

Alasan Utama Orang Menggunakan Internet

\begin{tabular}{|c|c|}
\hline Keterangan & Persentase (\%) \\
\hline Komunikasi Lewat Pesan & $24,7 \%$ \\
\hline Social media & $18,9 \%$ \\
\hline Mencari Informasi Terkait Pekerjaan & $11,5 \%$ \\
\hline Mencari Data Terkait Sekolah & $9,6 \%$ \\
\hline Mengisi Waktu Luang & $6,5 \%$ \\
\hline Bermain Game Online & $5,7 \%$ \\
\hline Membaca Berita di Media Online & $5,5 \%$ \\
\hline Nonton Film dan Video & $5 \%$ \\
\hline Mencari Informasi Produk & $2,8 \%$ \\
\hline Jualan Online & $2,4 \%$ \\
\hline Tuntutan Pekerjaan & $2,2 \%$ \\
\hline Alasan Lainnya & $5,2 \%$ \\
\hline Total & $100 \%$ \\
\hline
\end{tabular}

Sumber: Data diolah, 2019

Tabel 2. diatas menyimpulkan bahwa dari keseluruhan pengguna internet memiliki tujuan utama sebesar $24,7 \%$ untuk berkomunikasi lewat pesan, sedangkan tujuan keduanya itu sebesar $18,9 \%$ itu untuk social media. Dapat diketahui bahwa perkembangan social media di Indonesia memiliki peluang yang besar untuk dijadikan sebagai tempat pemasaran bagi para pebisnis yang ingin memasarkan produk atau jasanya secara digital.

Salah satu social media yang banyak digunakan oleh orang Indonesia saat ini adalah Instagram. Instagram adalah social media yang berbasis sharing foto maupun video. Sama seperti social media lainnya, di Instagram kita dapat mencari banyak teman dengan cara follow dan followers. Kegiatan di social media ini dapat berupa like, comment di foto atau video, dapat juga berkirim pesan dengan dirrect messages, dan yang saat ini sedang populer yaitu Instastory yakni membagikan video dan foto kegiatan yang kita sedang jalani secara live dan berlaku selama 24 jam. Saat ini Instagram tidak hanya digunakan untuk sebatas posting foto dan video untuk kepentingan pribadi, tetapi sebagian besar perusahaan dan Influencer sudah menggunakan Instagram untuk lahan mereka berbisnis, dari perusahaan biasanya memposting foto produk dan video testimoni mereka untuk meyakinkan para calon pembeli. Perusahaan juga kini dapat bekerja sama dengan influencer untuk membuat promosi baik berupa konten foto, video yang menarik sehingga dapat menimbulkan minat konsumen untuk membeli produk yang di iklankan, dengan demikian Instagram dapat menjadi sumber penghasilan bagi para penjual online dan influencer.

Salah satu perusahaan yang sudah berdiri cukup lama pada tahun 2008, yaitu Denara Bali adalah perusahaan yang bergerak pada sektor industri kosmetik. Ibu Rahmawati selaku manajer pemasaran menyatakan bahwa perusahaan tersebut awalnya memasarkan produknya secara konvensional, yaitu memasarkan ke 
beberapa supermarket, dan toko oleh-oleh yang kebanyakan berada di Bali. Penjualan perusahaan terus berjalan seperti biasa tanpa ada peningkatan yang signifikan sampai akhir tahun 2018, namun pada akhir tahun 2018 perusahaan ingin berkembang, memperluas pangsa pasar dan memperoleh peningkatan pendapatan diiringi dengan adanya perkembangan teknologi saat ini dan beberapa pesaing yang sudah terlebih dahulu memanfaatkan penjualan secara online dan terbilang sukses di dunia online. Melihat peluang tersebut perusahaan mencoba berbagai macam cara, salah satunya dengan berjualan di social media. Penjualan Denara Bali dari awal tahun 2019 sampai saat ini terus meningkat secara perlahan di setiap bulannya. Denara Bali kini turut menerapkan social media marketing khususnya di Instagram, dan ingin mengetahui apakah social media marketing yang diterapkan di Instagram memberikan pengaruh yang signifikan terhadap perusahaan dari sudut pandang konsumen. Diterapkannya social media marketing juga berdampak pada meluasnya target market dari perusahaan, dengan berjualan secara online kini perusahaan dapat menjangkau seluruh warga negara Indonesia bahkan menjangkau pasar Internasional.

Social media marketing merupakan bagian penting dari strategi penjualan, pelayanan, komunikasi, dan pemasaran yang lebih besar dan lebih lengkap serta merefleksikan dan menyesuaikan diri dengan pasar dan orang-orang yang mengartikannya (Solis, 2010:9). Social media memiliki beberapa macam channel yang beragam diantaranya adalah blogs, social networking services, social media sharing services, social bookmarking services, social news services, social geolocation and meeting services, dan community building services (Zimmerman \& Sahlin, 2010:11-15).

Kotler \& Keller (2016:642) menyatakan bahwa social media merupakan alat atau cara yang dilakukan oleh perusahaan untuk membagikan informasi berupa teks, gambar, audio, dan video kepada konsumen atau sebaliknya. Social media juga digunakan sebagai wadah untuk komunitas online dimana orang yang terhubung dalam suatu komunitas tertentu dapat berkomunikasi di dunia maya. Jaringan social media ini merupakan bentuk baru dari dialog antara "consumer-toconsumer" dan "business-to-consumer" yang memiliki implikasi besar terhadap pemasar (Kotler \& Armstrong, 2012:141). Social media kini menjadi sebagai salah satu sarana yang digunakan para pengusaha untuk melakukan pemasaran produk atau yang biasa juga disebut dengan social media marketing.

Social media marketing adalah sebuah proses yang mendorong individu untuk melakukan promosi melalui situs web, produk, atau layanan mereka melalui saluran sosial online dan untuk berkomunikasi dengan memanfaatkan komunitas yang jauh lebih besar yang memiliki kemungkinan lebih besar untuk melakukan pemasaran daripada melalui saluran periklanan tradisional (Weiberg, 2009:3-4). Social media marketing yang dilakukan oleh suatu bisnis dapat mempengaruhi pemikiran seseorang yang akan berdampak pada pemikiran orang lainnya secara lebih luas sebelum melakukan keputusan pembelian (Gunelius, 2011:144-145).

Penelitian yang dilakukan oleh Mileva \& Fauzi (2018) yang berjudul "pengaruh social media marketing terhadap keputusan pembelian (survei online pada mahasiswa sarjana Jurusan Ilmu Administrasi Bisnis angkatan 2014/2015 Fakultas Ilmu Administrasi Universitas Brawijaya yang membeli Starbucks 
menggunakan Line)" menemukan hasil bahwa social media marketing berpengaruh positif dan signifikan terhadap keputusan pembelian. Hasil ini sejalan dengan penelitian yang dilakukan oleh Pamungkas \& Zuhroh (2016) yang berjudul "pengaruh promosi di media sosial dan word of mouth terhadap keputusan pembelian (studi kasus pada Kedai Bontacos, Jombang)" juga menemukan hasil yang sama dan menyimpulkan bahwa promosi melalui social media menjadi strategi pemasaran yang cukup efektif, serta didukung dengan word of mouth yang positif akan mampu menarik konsumen untuk melakukan pembelian di Kedai Bontacos, namun berbeda dengan penelitian yang dilakukan oleh Zanjabila \& Hidayat (2017) yang berjudul "analisis pengaruh social media marketing terhadap keputusan pembelian Bandung Techno Park (studi pada pelanggan Bandung Techno Park)" menemukan hasil yang berbeda yaitu social media marketing berpengaruh positif namun tidak siginfikan terhadap keputusan pembelian, hal ini terjadi akibat para pengunjung menggunakan sosmed hanya untuk keperluan mencari informasi di Bandung Techno Park, selain social media marketing yang mampu mendorong orang untuk melakukan keputusan pembelian, terdapat faktor brand image juga mempengaruhi keputusan pembelian.

Strategi pemasaran suatu produk adalah meningkatkan brand image perusahaan. Kotler \& Keller (2012:274) menyatakan bahwa citra merek (brand image) merupakan persepsi masyarakat terhadap perusahaan atau produknya. Brand image merupakan deskripsi tentang asosiasi dan keyakinan konsumen tentang merek tertentu, sedangkan asosiasi merupakan atribut yang ada didalam merek itu dan memiliki suatu tingkat kekuatan (Tjiptono, 2011:49). Kotler \& Keller (2009) menyatakan bahwa citra adalah sejumlah keyakinan, ide, dan kesan yang dipegang oleh seseorang tentang sebuah objek. Membangun brand yang positif bisa didapatkan dengan cara membuat program marketing yang kuat terhadap produk tersebut sehingga produk kita memiliki ciri khas yang unik dan memiliki kelebihan yang ditonjolkan, dan yang dapat menjadikannya berbeda dengan produk lainnya.

Denara Bali melakukan rebranding pada segi kemasan produknya pada tahun 2018, menjadi lebih modern dan tampil lebih segar, perubahan tampilan kemasan ini dilakukan agar meyakinkan konsumen bahwa produk yang dimiliki Denara Bali memiliki kualitas yang baik, selain itu beberapa konsumen memberikan sebuah review mengenai produk Denara Bali di salah satu forum diskusi dan memberikan pendapat bahwa produk yang dimiliki oleh Denara Bali memiliki aroma yang tidak menyengat dan kualitas yang baik sehingga konsumen senang untuk menggunakan produk Denara Bali (www.forum.femaledaily.com, 2010). Selama ini konsumen yang sudah pernah membeli produk Denara Bali selalu senang menggunakan produk dan merekomendasikan produk kepada orang lain, Ini membuktikan bahwa brand image yang baik juga diperlukan agar produk dapat dipercaya oleh konsumen. Penelitian ini menggunakan variabel brand image sebagai variabel mediasi untuk memperkuat dari social media marketing yang diterapkan oleh perusahaan.

Penelitian yang dilakukan oleh (Saputri \& Pranata, 2014) mengungkapkan bahwa brand image mempunyai pengaruh terhadap loyalitas penggunaaan produk. Hasil yang sama ditemukan pada penelitian Samad \& Wibowo (2016) menemukan bahwa citra merek berpengaruh positif dan signifikan terhadap keputusan 
pembelian. Semakin baik citra suatu merek, maka semakin tinggi keputusan konsumen untuk melakukan pembelian, sedangkan berdasarkan penelitian yang dilakukan oleh Lubis \& Hidayat (2017) dalam penelitiannya yang berjudul "pengaruh citra merek dan harga terhadap keputusan pembelian pada Sekolah Tinggi Ilmu Manajemen Sukma Medan" menemukan hasil bahwa secara parsial citra merek tidak berpengaruh terhadap keputusan pembelian.

Kotler \& Keller (2009:258) menyatakan bahwa merek adalah nama, istilah, lambang, dan desain ataupun kombinasinya untuk memperkuat identitas barang atau jasa dari salah satu penjual atau kelompok penjual dan untuk mendiferensiasikan produk mereka dari para pesaing. Tjiptono (2005:49) menyatakan citra merek adalah deskripsi asosiasi dan keyakinan konsumen terhadap merek tertentu, citra merek adalah pengamatan dan kepercayaan yang digenggam konsumen, seperti yang dicerminkan di asosiasi atau di ingatan konsumen".

Brand image merupakan aspek penting yang memiliki hubungan dengan produk. Menurut Godey et al. (2016) brand image dapat mempengaruhi persepsi dan sikap konsumen diberbagai kesempatan. Untuk membedakan produk yang satu terhadap produk lainnya walaupun produk tersebut sejenis maka diperlukan sifat khas dalam produk tersebut, sifat khas tersebut dapat dilihat dari brand image produk tersebut (Haryantana dan Ekawati, 2015). Untuk menciptakan nilai yang lebih dipikiran konsumen sehingga akan meningkatkan brand image maka produk yang dihasilkan harus baik dan berkualitas (Citra \& Santoso, 2016).

Brand image dapat memberikan keuntungan terhadap konsumen karena dapat membantu konsumen dalam mengidentifikasi keuntungan dan kualitas yang dimiliki produk (Ago et al., 2015). Tanzila et al. (2015) berpendapat brand image merupakan kepercayaan di mata konsumen sehingga konsumen akan mempercayai kualitas produk terhadap brand yang mereka telah percaya. Brand image memiliki peran penting dalam mengembangkan brand suatu produk karena brand image memiliki aspek reputasi dan kredibilitas yang akan digunakan konsumen sebagai pertimbangan dalam menggunakan suatu produk maupun jasa (Wijaya, 2013). Konsumen cenderung akan memiliki persepsi yang positif terhadap merek pioner (merek pertama pada suatu kategori produk) meskipun merek lainnya muncul (Suryonaningsih et al., 2016).

Social media marketing adalah sebuah proses yang mendorong individu untuk melakukan promosi melalui situs web, produk, atau layanan mereka melalui saluran sosial online dan untuk berkomunikasi dengan memanfaatkan komunitas yang jauh lebih besar yang memiliki kemungkinan lebih besar untuk melakukan pemasaran daripada melalui saluran periklanan tradisional (Weinberg, 2009:3-4). Brand image adalah bagaimana citra perusahaan yang tertanam di benak konsumen. Pemanfaatan social media marketing yang tepat akan semakin menanamkan merek kepada konsumen. Anizir \& Wahyuni (2017), Angkie \& Tanoto (2019) menemukan bahwa social media marketing berpengaruh positif dan signifikan terhadap brand image. Sejalan juga dengan penelitian yang dilakukan oleh Ridho (2013) dengan penelitiannya yang menunjukkan hasil bahwa e-marketing berpengaruh positif dan signifikan terhadap citra merek. Berdasarkan uraian tersebut maka hipotesis yang diajukan dalam penelitian ini adalah: 
$\mathrm{H}_{1} \quad$ : Social media marketing berpengaruh positif dan signifikan terhadap brand image

Social media marketing adalah sebuah proses yang mendorong individu untuk melakukan promosi melalui situs web, produk, atau layanan mereka melalui saluran sosial online dan untuk berkomunikasi dengan memanfaatkan komunitas yang jauh lebih besar yang memiliki kemungkinan lebih besar untuk melakukan pemasaran daripada melalui saluran periklanan tradisional (Weiberg, 2009:3-4). Pemanfaatan social media marketing yang tepat akan meningkatkan keputusan pembelian karena konsumen semakin sering melihat produk kita. Mileva \& Fauzi (2018), Pamungkas \& Zuhroh (2016) dalam penelitiannya menemukan bahwa social media marketing berpengaruh positif dan signifikan terhadap keputusan pembelian, namun berbeda dengan penelitian yang dilakukan oleh Zanjabila \& Hidayat (2017) menemukan bahwa social media marketing berpengaruh positif namun tidak signifikan terhadap keputusan pembelian. Berdasarkan uraian tersebut maka hipotesis yang diajukan dalam penelitian ini adalah:

$\mathrm{H}_{2}$ : Social media marketing berpengaruh positif dan signifikan terhadap keputusan pembelian

Brand image baik tentu akan meningkatkan keputusan pembelian karena semakin baik citra perusahaan yeng tertanam di benak konsumen tentu akan membuat orang tersebut percaya kepada produk kita dan akan membeli produk kita. Samad \& Wibowo (2016), Lubis \& Wibowo (2016), Bramantya \& Jatra (2016) dalam penelitiannya menemukan bahwa brand image berpengaruh positif dan signifikan terhadap keputusan pembelian, namun hasil penelitian yang dilakukan oleh Foster (2017) dalam penelitiannya menemukan hasil bahwa brand image berpengaruh secara positif namun tidak signifikan terhadap keputusan pembelian. Berdasarkan uraian tersebut maka hipotesis yang diajukan dalam penelitian ini adalah:

$\mathrm{H}_{3}$ : Brand image berpengaruh positif dan signifikan terhadap keputusan pembelian

Pengaruh social media marketing terhadap keputusan pembelian dapat berupa pengaruh tidak langsung, karena social media marketing dapat mempengaruhi salah satu faktor merek yaitu brand image. Pemanfaatan social media marketing yang efektif dapat meningkatkan brand image. Perusahaan yang memiliki brand image yang baik tentu akan membuat konsumen semakin percaya dan melalukan keputusan pembelian. Ayuningtyas (2019) dalam penelitiannya menemukan bahwa terpaan media sosial Instagram berpengaruh signifikan terhadap proses keputusan berkunjung dengan citra destinasi sebagai variabel mediasi. Berdasarkan uraian tersebut maka hipotesis yang diajukan dalam penelitian ini adalah

$\mathrm{H}_{4}$ : Brand image mampu memediasi social media marketing terhadap keputusan pembelian

Penelitian yang dilakukan oleh Mileva \& Fauzi (2018) yang berjudul "pengaruh social media marketing terhadap keputusan pembelian (survei online pada mahasiswa sarjana Jurusan Ilmu Administrasi Bisnis angkatan 2014/2015 Fakultas Ilmu Administrasi Universitas Brawijaya yang membeli Starbucks menggunakan Line)" menemukan hasil bahwa social media marketing berpengaruh 
positif dan signifikan terhadap keputusan pembelian. Hasil ini sejalan dengan penelitian yang dilakukan oleh Pamungkas \& Zuhroh (2016) yang berjudul "pengaruh promosi di media sosial dan word of mouth terhadap keputusan pembelian (studi kasus pada Kedai Bontacos, Jombang)" juga menemukan hasil yang sama dan menyimpulkan bahwa promosi melalui social media menjadi strategi pemasaran yang cukup efektif, serta didukung dengan word of mouth yang positif akan mampu menarik konsumen untuk melakukan pembelian di Kedai Bontacos, namun berbeda dengan penelitian yang dilakukan oleh Zanjabila \& Hidayat (2017) yang berjudul "analisis pengaruh social media marketing terhadap keputusan pembelian Bandung Techno Park (studi pada pelanggan Bandung Techno Park)" menemukan hasil yang berbeda yaitu social media marketing berpengaruh positif namun tidak siginfikan terhadap keputusan pembelian, hal ini terjadi akibat para pengunjung menggunakan sosmed hanya untuk keperluan mencari informasi di Bandung Techno Park, selain social media marketing yang mampu mendorong orang untuk melakukan keputusan pembelian, terdapat faktor brand image juga mempengaruhi keputusan pembelian.

Strategi pemasaran suatu produk adalah meningkatkan brand image perusahaan. Kotler \& Keller (2012:274) menyatakan bahwa citra merek (brand image) merupakan persepsi masyarakat terhadap perusahaan atau produknya. Brand image merupakan deskripsi tentang asosiasi dan keyakinan konsumen tentang merek tertentu, sedangkan asosiasi merupakan atribut yang ada didalam merek itu dan memiliki suatu tingkat kekuatan (Tjiptono, 2011:49). Kotler \& Keller (2009) menyatakan bahwa citra adalah sejumlah keyakinan, ide, dan kesan yang dipegang oleh seseorang tentang sebuah objek. Membangun brand yang positif bisa didapatkan dengan cara membuat program marketing yang kuat terhadap produk tersebut sehingga produk kita memiliki ciri khas yang unik dan memiliki kelebihan yang ditonjolkan, dan yang dapat menjadikannya berbeda dengan produk lainnya.

Denara Bali melakukan rebranding pada segi kemasan produknya pada tahun 2018, menjadi lebih modern dan tampil lebih segar, perubahan tampilan kemasan ini dilakukan agar meyakinkan konsumen bahwa produk yang dimiliki Denara Bali memiliki kualitas yang baik, selain itu beberapa konsumen memberikan sebuah review mengenai produk Denara Bali di salah satu forum diskusi dan memberikan pendapat bahwa produk yang dimiliki oleh Denara Bali memiliki aroma yang tidak menyengat dan kualitas yang baik sehingga konsumen senang untuk menggunakan produk Denara Bali (www.forum.femaledaily.com, 2010). Selama ini konsumen yang sudah pernah membeli produk Denara Bali selalu senang menggunakan produk dan merekomendasikan produk kepada orang lain, Ini membuktikan bahwa brand image yang baik juga diperlukan agar produk dapat dipercaya oleh konsumen. Penelitian ini menggunakan variabel brand image sebagai variabel mediasi untuk memperkuat dari social media marketing yang diterapkan oleh perusahaan.

Penelitian yang dilakukan oleh (Saputri \& Pranata, 2014) mengungkapkan bahwa brand image mempunyai pengaruh terhadap loyalitas penggunaaan produk. Hasil yang sama ditemukan pada penelitian Samad \& Wibowo (2016) menemukan bahwa citra merek berpengaruh positif dan signifikan terhadap keputusan pembelian. Semakin baik citra suatu merek, maka semakin tinggi keputusan 
konsumen untuk melakukan pembelian, sedangkan berdasarkan penelitian yang dilakukan oleh Lubis \& Hidayat (2017) dalam penelitiannya yang berjudul "pengaruh citra merek dan harga terhadap keputusan pembelian pada Sekolah Tinggi Ilmu Manajemen Sukma Medan" menemukan hasil bahwa secara parsial citra merek tidak berpengaruh terhadap keputusan pembelian.

\section{METODE PENELITIAN}

Lokasi yang digunakan dalam penelitian ini adalah Kota Denpasar, Bali, karena Kota Denpasar dinilai sebagai lokasi yang strategis dan merupakan pusat pertumbuhan perekonomian dari Provinsi Bali, yang sebagian besar masyarakatnya sudah mengikuti perkembangan jaman, sehingga lokasi ini dinilai cocok untuk menjadi tempat mengadakan penelitian. Objek dalam penelitian ini adalah perilaku konsumen yakni keputusan pembelian produk Denara Bali oleh konsumen yang dimediasi oleh brand image dan dipengaruhi oleh social media marketing. Subjek dalam penelitian ini adalah seluruh masyarakat yang tinggal dan berada di Kota Denpasar yang sudah pernah membeli produk dari Denara Bali.

Dalam penelitian ini, populasinya adalah masyarakat Kota Denpasar yang sudah pernah membeli produk Denara Bali. Ukuran besarnya sampel yaitu paling sedikit 60 dan paling banyak 120, jumlah ini didapat berdasarkan jumlah indikator yaitu 12 indikator.

Teknik penentuan sampel pada penelitian ini menggunakan teknik non probability sampling dengan metode purposive sampling, yaitu penarikan sampel berdasarkan tujuan dari peneliti dilihat dari sudut pandang pertimbangan informasi yang dibutuhkan dan dari sudut pandang kuota yang dibutuhkan (quota sampling).

Analisis jalur digunakan untuk menguji pengaruh variabel intervening. Analisis jalur merupakan perluasan dari analisis linear berganda, analisis jalur dalam penggunaan analisis regresi untuk menaksir hubungan kausalitas antar variabel (model casual) yang telah ditetapkan sebelumnya berdasarkan teori.

Analisis jalur sendiri tidak dapat menentukan hubungan sebab akibat dan juga tidak dapat digunakan sebagai substitusi bagi peneliti untuk melihat hubungan kausalitas antar variabel. Hubungan kausalitas antar variabel telah dibentuk dengan model berdasarkan landasan teoritis. Apa yang dapat dilakukan analisis jalur menentukan pola hubungan antara tiga atau lebih variabel dan tidak dapat digunakan untuk mengkonfirmasi atau menolak hipotesis kausalitas imajiner (Ghozali, 2013:249). Menurut kerangka berfikir yang telah disebutkan diatas maka dalam analisis jalur akan ada dua persamaan yaitu:

$\mathrm{M}=\mathrm{b}_{1} \mathrm{X}+\mathrm{e}_{1}$

$\mathrm{Y}=\mathrm{b}_{2} \mathrm{X}+\mathrm{b}_{3} \mathrm{M}+\mathrm{e}_{2}$

Dimana:

$\mathrm{Y}=$ Keputusan Pembelian

$\mathrm{X}=$ Social media marketing

$\mathrm{M}=$ Brand image

b1 = Koefisien social media marketing

b2 = Koefisien brand image

b3 $=$ Koefisien keputusan pembelian 
e1 = Variabel pengganggu social media marketing

e2 $=$ Variabel pengganggu keputusan pembelian

\section{HASIL DAN PEMBAHASAN}

Uji validitas dilakukan dengan mengkorelasikan antara skor faktor dengan skor total dan bila korelasi tiap faktor tersebut bernilai positif ( $\mathrm{r}>0,3)$, maka instrumen penelitian tersebut dapat dikatakan valid. Instrumen yang valid adalah instrumen yang dapat digunakan untuk mengukur apa yang seharusnya diukur. Tinggi rendahnya validitas menunjuk kan sejauh mana data yang terkumpul tidak menyimpang dari gambaran tentang variabel yang dimaksud. Hasil uji validitas penelitian ini ditunjukkan dalam Tabel 3. berikut ini:

Tabel 3.

Rekapitulasi Hasil Uji Validitas Instrumen Penelitian

\begin{tabular}{|c|c|c|c|c|}
\hline No. & Variabel & Instrumen & $\begin{array}{c}\text { Pearson } \\
\text { Correlation }\end{array}$ & Keterangan \\
\hline \multirow{5}{*}{1.} & \multirow{4}{*}{ Social media marketing $(\mathrm{X})$} & $\mathrm{X} 1$ & 0,806 & Valid \\
\hline & & $\mathrm{X} 2$ & 0,916 & Valid \\
\hline & & $\mathrm{X} 3$ & 0,908 & Valid \\
\hline & & $\mathrm{X} 4$ & 0,914 & Valid \\
\hline & \multirow{4}{*}{ Brand image $(\mathrm{M})$} & M1 & 0,947 & Valid \\
\hline \multirow[t]{4}{*}{2.} & & M2 & 0,966 & Valid \\
\hline & & M3 & 0,963 & Valid \\
\hline & & Y1 & 0,976 & Valid \\
\hline & & Y2 & 0,949 & Valid \\
\hline \multirow[t]{3}{*}{3.} & Keputusan Pembelian (Y) & Y3 & 0,877 & Valid \\
\hline & & Y4 & 0,956 & Valid \\
\hline & & Y5 & 0,937 & Valid \\
\hline
\end{tabular}

Sumber: Data diolah, 2018

Tabel 3. menyimpulkan bahwa seluruh instrumen variabel penelitian berupa social media marketing, brand image dan keputusan pembelian telah memenuhi syarat uji validitas yang dimana nilai skor total pearson correlation masing-masing instrumen berada diatas 0,30 dan mimiliki nilai signifikansi yang lebih kecil dari $5 \%(0,05)$, maka instrumen layak digunakan menjadi alat ukur variabel-variabel tersebut.

Pengujian ini, nilai suatu reliabilitas ditunjukkan melalui skor cronbach's alpha yang dimana jika nilai skor tersebut berada diatas 0,70 maka instrumen tersebut dapat dikatakan reliabel. Hasil penelitian uji reliabilitas dapat dilihat pada Tabel 4.

Tabel 4.

Hasil Uji Reliabilitas Instrumen Penelitian

\begin{tabular}{llcc}
\hline No. & \multicolumn{1}{c}{ Variabel } & Cronbach's Alpha & Keterangan \\
\hline 1. & Social media marketing $(\mathrm{X})$ & 0,909 & Reliabel \\
2. & Brand image $(\mathrm{M})$ & 0,953 & Reliabel \\
3. & Keputusan Pembelian $(\mathrm{Y})$ & 0,966 & Reliabel \\
\hline \multicolumn{2}{l}{ Sumber: Data diolah, 2019}
\end{tabular}


Tabel 4. ditampilkan uji reliabilitas pada masing-masing variabel berada pada titik diatas 0,70 yang ditunjukkan pada hasil cronbach's alpha, maka dapat dikatakan seluruh instrumen telah memenuhi syarat reliabilitas.

Pengujian normalitas pada penilitian ini dilakukan menggunakan analisis grafik histogram, normal probability plot dan analisis statistik One-Sample Kolmogorov-Smirnov, yaitu dengan membandingkan Kolmogorov-Smirnov hitung dengan Kolmogorov-Smirnov. Hasil uji One-Sample Kolmogorov-Smirnov dapat ditampilkan dalam Tabel 5.

Tabel 5.

Uji Normalitas (One-Sample Kolmogorov-Smirnov)

\begin{tabular}{cl}
\hline Persamaan & Kolmogorov-Smirnov Z \\
\hline Substruktur 1 & 0,108 \\
Substruktur 2 & 0,258 \\
\hline Sumber: Data diolab, 2019
\end{tabular}

Sumber: Data diolah, 2019

Hasil uji normalitas dengan menggunakan One-Sample Kolmogorov-Smirnov Test yang ditampilkan pada Tabel 5. tersebut menunjukkan bahwa besarnya nilai Kolmogorov-Smirnov adalah sebesar 0,108 dan 0,258. Nilai Kolmogorov-Smirnov tersebut lebih besar dibandingkan dengan nilai Kolmogorov-Smirnov tabel sebesar 0,05 maka $\mathrm{H}_{\mathrm{o}}$ diterima yang mengindikasikan bahwa data yang digunakan pada penelitian ini terdistribusi normal, sehingga dapat disimpulkan bahwa model memenuhi asumsi normalitas.

Pengujian multikolinearitas dilakukan dengan menganalisis nilai tolerance dan nilai VIF. Nilai tolerance dan nilai VIF digunakan untuk mengukur variabilitas variabel independen atau hubungan antar variabel independen, jika nilai tolerance kurang dari 0,10 atau nilai $V I F$ lebih dari 10 maka menunjukkan adanya multikolinearitas. Adapun nilai tolerance dan nilai VIF ditunjukkan pada tabel 6 berikut:

Tabel 6.

Uji Multikolinieritas (Tolerance dan Variance Inflation Factor)

\begin{tabular}{|c|c|c|c|}
\hline & \multirow{2}{*}{ Model } & \multicolumn{2}{|c|}{ Collinearity Statistics } \\
\hline & & Tolerance & VIF \\
\hline \multirow{2}{*}{ Substruktur 2} & Social media marketing & 0.515 & 1.943 \\
\hline & Brand image & 0.515 & 1.943 \\
\hline
\end{tabular}

Sumber: Data diolah, 2019

Hasil Tabel 6. tersebut menunjukkan bahwa tidak terdapat variabel bebas yang memiliki nilai tolerance kurang dari 0,10 dan juga tidak ada variabel bebas yang memiliki nilai VIF lebih dari 10. Maka dari pada itu model regresi bebas dari gejala multikoleniaritas.

Pengujian heteroskedastisitas diakukan melalui metode glesjer dan dengan grafik scatterplot. Metode glesjer meregresikan model regresi untuk mendapatkan nilai residualnya, kemudian nilai residual tersebut diabsolutkan dan dilakukan regresi dengan semua variabel independen, bila terdapat variabel independen yang berpengaruh secara signifikan terhadap residual absolut maka terjadi 
heteroskedastisitas pada model regresi ini. Tabel 7. menunjukkan hasil perhitungan statistik dengan metode glesjer.

Tabel 7.

Uji Heteroskedastisitas (Uji Glesjer) Coefficients(a)

\begin{tabular}{|c|c|c|c|}
\hline Persamaan & Model & $\mathbf{T}$ & Sig. \\
\hline Substruktur 1 & Social media marketing & -1.092 & 0.277 \\
\hline Substruktur 2 & $\begin{array}{l}\text { Social media marketing } \\
\text { Brand image }\end{array}$ & $\begin{array}{l}-0.052 \\
-0.130\end{array}$ & $\begin{array}{l}0.959 \\
0.897\end{array}$ \\
\hline
\end{tabular}

Hasil Tabel 7. tersebut menunjukkan bahwa masing-masing model memiliki nilai signifikansi lebih besar dari 5\%. Hal ini menunjukkan bahwa variabel bebas yang digunakan pada penelitian ini tidak berpengaruh secara signifikan terhadap variabel terikatnya yaitu absolute error, maka dari itu, penelitian ini bebas dari gejala heteroskedastisitas.

Penelitian ini menghitung pengaruh Social media marketing terhadap brand image melalui program SPSS 21.0 for windows, berikut ini ditampilkan hasil perhitungan struktur pertama pada Tabel 8 .

Tabel 8.

\section{Hasil Analisis Jalur Pada Struktur 1}

\begin{tabular}{|c|c|c|c|c|c|c|}
\hline \multirow{2}{*}{\multicolumn{2}{|c|}{ Model }} & \multicolumn{2}{|c|}{$\begin{array}{l}\text { Unstandardized } \\
\text { Coefficients }\end{array}$} & \multirow{2}{*}{$\begin{array}{c}\text { Standardized } \\
\text { Coefficients } \\
\text { Beta } \\
\end{array}$} & \multirow[t]{2}{*}{$\mathbf{t}$} & \multirow[t]{2}{*}{ Sig. } \\
\hline & & B & Std. Error & & & \\
\hline (Constant) & & 0.868 & 0.247 & & 3.509 & 0.001 \\
\hline $\begin{array}{l}\text { Social } \\
\text { marketing }\end{array}$ & media & 0.733 & 0.069 & 0.697 & 10.549 & 0.000 \\
\hline $\mathrm{R}^{2}$ & $: 0,485$ & & & & & \\
\hline
\end{tabular}

Sumber: Data diolah, 2019

Hasil analisis jalur pada Tabel 8. maka dapat dirumuskan persamaan struktural yang terbentuk adalah sebagai berikut:

$$
\mathrm{M}=0,697 \mathrm{X}+\mathrm{e} 1
$$

Persamaan struktural tersebut dapat diartikan yaitu Variabel Social media marketing memiliki koefisien sebesar 0,697 berarti Social media marketing memiliki pengaruh positif terhadap Brand image, ini diartikan apabila Social media marketing meningkat maka Brand image akan meningkat sebesar 0,697.

Penelitian ini menghitung pengaruh social media marketing dan brand image terhadap keputusan pembelian melalui program SPSS 21.0 for windows, berikut ini ditampilkan hasil perhitungan struktur kedua pada Tabel 9.

Hasil analisis jalur pada Tabel 9. merumuskan persamaan struktural sebagai

berikut:

$$
\mathrm{Y}=0,310 \mathrm{X}+0,518 \mathrm{M}+\mathrm{e} 2
$$


Tabel 9.

Hasil Analisis Jalur Pada Struktur 2

\begin{tabular}{|c|c|c|c|c|c|}
\hline \multirow{2}{*}{ Model } & \multicolumn{2}{|c|}{$\begin{array}{c}\text { Unstandardized } \\
\text { Coefficients }\end{array}$} & \multirow{2}{*}{$\begin{array}{c}\text { Standardized } \\
\text { Coefficients } \\
\text { Beta } \\
\end{array}$} & \multirow[t]{2}{*}{$\mathbf{t}$} & \multirow[t]{2}{*}{ Sig. } \\
\hline & B & Std. Error & & & \\
\hline (Constant) & 0.163 & 0.259 & & 0.627 & 0.532 \\
\hline Social media marketing & 0.362 & 0.097 & 0.310 & 3.752 & 0.000 \\
\hline Brand image & 0.575 & 0.092 & 0.518 & 6.256 & 0.000 \\
\hline $\mathrm{R}^{2} \quad: 0,588$ & & & & & \\
\hline
\end{tabular}

Sumber: Data diolah, 2019

Variabel social media marketing memiliki koefisien sebesar 0,310 berarti social media marketing memiliki pengaruh positif terhadap keputusan pembelian, ini diartikan apabila social media marketing meningkat maka keputusan pembelian akan meningkat sebesar 0,310 .

Variabel brand image memiliki koefisien sebesar 0,518 berarti brand image memiliki pengaruh positif terhadap keputusan pembelian, ini diartikan apabila brand image meningkat maka keputusan pembelian akan meningkat sebesar 0,518.

Pengujian ini akan melihat nilai masing-masing koefisien determinasi untuk struktur 1 dan struktur 2 serta nilai masing-masing variabel error pada setiap struktur dengan tujuan penyusunan model diagram jalur akhir, berikut ini hasil perhitungan nilai variabel error pada setiap struktur.

$$
\begin{aligned}
& \mathrm{e}_{\mathrm{i}}=\sqrt{1-\mathrm{R}_{\mathrm{i}}{ }^{2}} \ldots \ldots \ldots \ldots \ldots \ldots \ldots \ldots \ldots \ldots \ldots \\
& \mathrm{e}_{1}=\sqrt{1-R_{1}{ }^{2}}=\sqrt{1-0,485}=0,718 \\
& \mathrm{e}_{2}=\sqrt{1-R_{2}{ }^{2}}=\sqrt{1-0,588}=0,642
\end{aligned}
$$

Perhitungan pengaruh error (e) didapatkan hasil untuk pengaruh error struktur $1\left(\mathrm{e}_{1}\right)$ sebesar 0,718 dan pengaruh error struktur $2\left(\mathrm{e}_{2}\right)$ sebesar 0,642, selanjutnya akan dihitung koefisien determinasi total adalah sebagai berikut:

$$
\begin{aligned}
\mathrm{R}^{2}{ }_{\mathrm{m}} & =1-\left(\mathrm{e}_{1}\right)^{2}\left(\mathrm{e}_{2}\right)^{2} \ldots \ldots \ldots \\
& =1-(0,718)^{2}(0,642)^{2} \\
& =1-(0,515)(0,412) \\
& =1-0,212=0,788
\end{aligned}
$$

Hasil perhitungan nilai koefisien determinasi total didapatkan sebesar 0,788, maka kesimpulannya adalah 78,8\% variabel keputusan pembelian pada konsumen Denara Bali di Kota Denpasar dipengaruhi oleh social media marketing, dan brand image, sedangkan sisanya $21,2 \%$ dipengaruhi oleh faktor lain yang tidak dimasukkan dalam model penelitian atau diluar model penelitian.

Berdasarkan hasil pada Tabel 8 social media marketing memiliki nilai Beta sebesar 0,697 dan nilai Sig. sebesar 0,000, maka dapat dikatakan $\mathrm{H}_{\mathrm{a}}$ diterima karena nilai Sig. 0,000 < 0,05. Kesimpulannya adalah bahwa social media marketing memiliki pengaruh positif dan signifikan terhadap brand image, dengan kata lain semakin meningkat social media marketing pada Denara Bali di Kota Denpasar, maka semakin meningkat brand image pada konsumen Denara Bali di Kota Denpasar. Sehingga hipotesis pertama diterima. 
Berdasarkan hasil pada Tabel 9. social media marketing memiliki nilai Beta sebesar 0,310 dan nilai Sig. sebesar 0,000, maka dapat dikatakan $\mathrm{H}_{\mathrm{a}}$ diterima karena nilai Sig. 0,000 < 0,05. Kesimpulannya adalah social media marketing berpengaruh positif dan signifikan terhadap keputusan pembelian dengan kata lain semakin meningkat social media marketing maka keputusan pembelian pada konsumen Denara Bali di Kota Denpasar akan semakin meningkat. Sehingga hipotesis kedua diterima.

Berdasarkan hasil pada Tabel 9. brand image memiliki nilai Beta sebesar 0,518 dan nilai Sig. sebesar 0.000, maka dapat dikatakan $\mathrm{H}_{\mathrm{a}}$ diterima karena nilai Sig. $0.000<0,05$. Kesimpulannya adalah bahwa brand image memiliki pengaruh positif dan signifikan terhadap keputusan pembelian, dengan kata lain apabila brand image meningkat maka keputusan pembelian pada konsumen Denara Bali di Kota Denpasar akan semakin meningkat. Sehingga hipotesis ketiga diterima.

Uji sobel merupakan alat analisis untuk menguji signifikansi dari hubungan tidak langsung antara variabel independen dengan variabel dependen yang dimediasi oleh variabel mediator. Uji Sobel dirumuskan dengan persamaan berikut dan dapat dihitung dengan menggunakan aplikasi Microsoft Excel 2010. Bila nilai kalkulasi Z lebih besar dari 1,96 (dengan tingkat kepercayaan 95 persen), maka variabel mediator dinilai secara signifikan memediasi hubungan antara variabel terikat dan variabel bebas.

$$
\mathrm{Z}=\frac{\mathrm{ab}}{\sqrt{\mathrm{b}^{2} \mathrm{~S}_{\mathrm{a}}^{2}+\mathrm{a}^{2} \mathrm{~S}_{\mathrm{b}}^{2}+\mathrm{S}_{\mathrm{a}}^{2} \mathrm{~S}_{\mathrm{b}}^{2}}}
$$

Keterangan :

$\mathrm{a}=0,697$

$\mathrm{S}_{\mathrm{a}}=0,069$

$\mathrm{b}=0,518$

$\mathrm{S}_{\mathrm{b}}=0,092$

Sumber: Baron and Kenny (1986)

$$
\begin{aligned}
Z & =\frac{0,697 \cdot 0,518}{\sqrt{\left(0,518^{2} 0,069^{2}\right)+\left(0,697^{2} 0,092^{2}\right)+\left(0,069^{2} 0,092^{2}\right)}} \\
Z & =\frac{0,361}{0,074} \\
Z & =4,900
\end{aligned}
$$

Berdasarkan hasil Uji Sobel menunjukkan bahwa hasil tabulasi $\mathrm{Z}=$ 4,900>1,96 yang berarti variabel social media marketing berpengaruh positif dan signifikan terhadap keputusan pembelian pada konsumen Denara Bali di Kota Denpasar dengan mediasi brand image, sehingga brand image merupakan variabel mediasi pengaruh antara social media marketing terhadap keputusan pembelian pada konsumen Denara Bali di Kota Denpasar, Sehingga hipotesis keempat diterima.

Hasil hipotesis dalam penelitian ini menunjukkan bahwa social media marketing memiliki pengaruh positif dan signifikan terhadap brand image, dengan 
kata lain semakin meningkat social media marketing pada Denara Bali di Kota Denpasar, maka semakin tinggi tingkat brand image pada konsumen Denara Bali di Kota Denpasar. Hal ini sejalan dengan hasil penelitian yang dilakukan oleh Mileva \& Fauzi (2018) dalam penelitiannya yang berjudul "pengaruh social media marketing terhadap keputusan pembelian (survei online pada mahasiswa sarjana Jurusan Ilmu Administrasi Bisnis angkatan 2014/2015 Fakultas Ilmu Administrasi Universitas Brawijaya yang membeli Starbucks menggunakan Line)" menemukan bahwa social media marketing berpengaruh positif dan signifikan terhadap keputusan pembelian. Serupa dengan penelitian yang dilakukan oleh Pamungkas \& Zuhroh (2016) yang berjudul "pengaruh promosi di media sosial dan word of mouth terhadap keputusan pembelian (studi kasus pada Kedai Bontacos, Jombang)" menemukan bahwa promosi melalui media sosial berpengaruh positif dan signifikan terhadap keputusan pembelian di Bontacos, namun berbeda dengan penelitian yang dilakukan oleh Zanjabila \& Hidayat (2017) yang berjudul "analisis pengaruh social media marketing terhadap keputusan pembelian Bandung Techno Park (studi pada pelanggan Bandung Techno Park 2017)" menemukan bahwa social media marketing berpengaruh positif namun tidak signifikan terhadap keputusan pembelian, sebab pengunjung Bandung Techno Park menggunakan social media sebagai media pencari informasi saja.

Hasil hipotesis dalam penelitian ini menunjukkan bahwa social media marketing berpengaruh positif dan signifikan terhadap keputusan pembelian dengan kata lain semakin meningkat social media marketing maka keputusan pembelian pada konsumen Denara Bali di Kota Denpasar akan semakin meningkat. Hal ini sejalan dengan hasil penelitian yang dilakukan oleh Anizir \& Wahyuni (2017) dalam penelitiannya yang berjudul "pengaruh social media marketing terhadap brand image perguruan tinggi swasta di Kota Serang" menemukan bahwa social media marketing berpengaruh positif dan signifikan terhadap brand image. Sejalan dengan penelitian yang dilakukan oleh Angkie \& Tanoto (2019) yang berjudul "pengaruh social media marketing terhadap brand equity pada Brand Fashion Zara, H\&M, Pull\&Bear, dan Stradivarius di Surabaya" menemukan bahwa social media marketing berpengaruh positif dan signifikan terhadap brand equity. Sejalan juga dengan penelitian yang dilakukan oleh Ridho (2013) dengan penelitiannya yang berjudul "pengaruh e-marketing terhadap citra merek Nay@dam pada PT. Kreasi Putra Serayu" menunjukkan hasil bahwa e-marketing berpengaruh positif dan signifikan terhadap citra merek.

Hasil hipotesis dalam penelitian ini menunjukkan bahwa brand image memiliki pengaruh positif dan signifikan terhadap keputusan pembelian, dengan kata lain apabila brand image meningkat maka keputusan pembelian pada konsumen Denara Bali di Kota Denpasar akan semakin meningkat. Hasil penelitian ini sesuai dengan penelitian yang dilakukan oleh Mileva \& Fauzi (2018) dalam penelitiannya yang berjudul "pengaruh social media marketing terhadap keputusan pembelian (survei online pada mahasiswa sarjana Jurusan Ilmu Administrasi Bisnis angkatan 2014/2015 Fakultas Ilmu Administrasi Universitas Brawijaya yang membeli Starbucks menggunakan Line)" menemukan bahwa social media marketing berpengaruh positif dan signifikan terhadap keputusan pembelian. Sejalan dengan penelitian yang dilakukan oleh Pamungkas \& Zuhroh (2016) yang 
berjudul "pengaruh promosi di media sosial dan word of mouth terhadap keputusan pembelian (studi kasus pada Kedai Bontacos, Jombang)" menemukan bahwa promosi melalui media sosial berpengaruh positif dan signifikan terhadap keputusan pembelian di Bontacos, namun berbeda dengan penelitian yang dilakukan oleh Zanjabila \& Hidayat (2017) yang berjudul analisis pengaruh social media marketing terhadap keputusan pembelian Bandung Techno Park (studi pada pelanggan Bandung Techno Park 2017)" menemukan bahwa social media marketing berpengaruh positif namun tidak signifikan terhadap keputusan pembelian, sebab pengunjung Bandung Techno Park menggunakan social media sebagai media pencari informasi saja.

Hasil hipotesis dalam penelitian ini menunjukkan bahwa social media marketing berpengaruh positif dan signifikan terhadap keputusan pembelian pada konsumen Denara Bali di Kota Denpasar dengan mediasi brand image, sehingga brand image merupakan variabel mediasi pengaruh antara social media marketing terhadap keputusan pembelian pada konsumen Denara Bali di Kota Denpasar. Hasil penelitian ini sejalan dengan penelitian yang dilakukan oleh Ayuningtyas dkk. (2019) dalam penelitiannya yang berjudul "pengaruh terpaan media sosial Instagram terhadap keputusan berkunjung dengan citra destinasi sebagai variabel mediasi (survei pada pengunjung Kampung Tridi (tiga dimensi) Malang)" menemukan bahwa terpaan media sosial Instagram berpengaruh signifikan terhadap proses keputusan berkunjung dengan citra destinasi sebagai variabel mediasi.

Implikasi teoritis dari hasil penelitian ini adalah untuk memberikan konfirmasi dari hasil pengujian yang sudah dilakukan oleh peneliti sebelumnya mengenai hubungan antara variabel social media marketing, brand image dan keputusan pembelian. Secara teoritis penelitian ini juga memberikan pemahaman bahwa social media marketing dan brand image secara nyata dapat meningkatkan keputusan pembelian, ketika social media marketing meningkatkan brand image, maka brand image yang dirasakan oleh konsumen menjadi semakin kuat sehingga berpotensi meningkatkan keputusan pembelian.

Secara praktis dapat menjadi referensi bagi perusahaan Denara Bali dalam mengetahui bagaimana pengaruh dari social media marketing yang sudah diterapkan terhadap keputusan pembelian konsumen, serta bagaimana brand image tentang perusahaan yang selama ini tertanam di benak konsumen. Admin Instagram Denara Bali harus lebih rajin dalam memposting konten agar social media marketing dapat berjalan secara efektif, sehingga akan semakin meningkatkan keputusan pembelian, serta harus tetap mempertahankan format informasi yang lengkap melalui konten Instagram. Brand image mengenai produk yang memiliki semangat jiwa muda masih belum berhasil tertanam di benak konsumen, maka dari itu perusahaan harus membuat konten dengan campaign sesuai dengan selera anak muda, sehingga akan tertanam di benak konsumen bahwa produk Denara Bali memang diperuntukkan bagi seseorang yang memiliki semangat berjiwa muda. Konsumen juga menyatakan bahwa tidak sering untuk membeli produk Denara Bali, sebaiknya perusahaan lebih efektif dalam menerapkan social media marketing dan lebih menekankan brand image sesuai dengan target market yang ingin disasar, 
sehingga dapat membuat konsumen lebih sering untuk membeli produk Denara Bali.

Implikasi teoritis dari hasil penelitian ini adalah untuk memberikan konfirmasi dari hasil pengujian yang sudah dilakukan oleh peneliti sebelumnya mengenai hubungan antara variabel social media marketing, brand image dan keputusan pembelian. Secara teoritis penelitian ini juga memberikan pemahaman bahwa social media marketing dan brand image secara nyata dapat meningkatkan keputusan pembelian, ketika social media marketing meningkatkan brand image, maka brand image yang dirasakan oleh konsumen menjadi semakin kuat sehingga berpotensi meningkatkan keputusan pembelian.

Secara praktis dapat menjadi referensi bagi perusahaan Denara Bali dalam mengetahui bagaimana pengaruh dari social media marketing yang sudah diterapkan terhadap keputusan pembelian konsumen, serta bagaimana brand image tentang perusahaan yang selama ini tertanam di benak konsumen. Admin Instagram Denara Bali harus lebih rajin dalam memposting konten agar social media marketing dapat berjalan secara efektif, sehingga akan semakin meningkatkan keputusan pembelian, serta harus tetap mempertahankan format informasi yang lengkap melalui konten Instagram. Brand image mengenai produk yang memiliki semangat jiwa muda masih belum berhasil tertanam di benak konsumen, maka dari itu perusahaan harus membuat konten dengan campaign sesuai dengan selera anak muda, sehingga akan tertanam di benak konsumen bahwa produk Denara Bali memang diperuntukkan bagi seseorang yang memiliki semangat berjiwa muda. Konsumen juga menyatakan bahwa tidak sering untuk membeli produk Denara Bali, sebaiknya perusahaan lebih efektif dalam menerapkan social media marketing dan lebih menekankan brand image sesuai dengan target market yang ingin disasar, sehingga dapat membuat konsumen lebih sering untuk membeli produk Denara Bali.

\section{SIMPULAN}

Social media marketing berpengaruh positif dan signifikan terhadap brand image pada konsumen Denara Bali di Kota Denpasar. Semakin baik social media marketing yang diterapkan maka akan menigkatkan brand image. Social media marketing berpengaruh positif dan signifikan terhadap keputusan pembelian pada konsumen Denara Bali di Kota Denpasar. Semakin baik social media marketing yang diterapkan maka akan menigkatkan keputusan pembelian. Brand image berpengaruh positif dan signifikan terhadap keputusan pembelian pada konsumen Denara Bali di Kota Denpasar. Semakin baik brand image yang tertanam di benak konsumen akan dapat meningkatkan keputusan pembelian. Brand image merupakan variabel mediasi pengaruh antara social media marketing terhadap keputusan pembelian pada konsumen Denara Bali di Kota Denpasar. Hal ini menunjukan bahwa penerapan social media marketing sangat berpengaruh terhadap keputusan pembelian jika diperkuat oleh brand image positif yang tertanam di benak konsumen.

Bagi Denara Bali, perusahaan harus tetap mengoptimalkan dalam penggunaan social media marketing di dalam memasarkan produk, dalam hal ini yaitu lebih konsisten dalam mengupload konten sehingga akan meningkatkan 
keputusan pembelian, dari segi brand image hal yang harus dilakukan oleh perusahaan adalah tetap mempertahankan citra perusahaan yang sudah baik dan memberikan pemahaman kepada konsumen dengan cara membuat konten dengan campaign yang menyasar kalangan anak muda, agar perusahaan dapat membangun brand image yang mencirikan seseorang yang memiliki semangat berjiwa muda.

Bagi peneliti selanjutnya, diharapkan mampu menambah variabel- variabel lainnya yang dapat mempengaruhi keputusan pembelian seperti brand awareness, saluran distribusi, harga, kualitas, dll. Mampu untuk memperluas ruang lingkup penelitian yang tidak hanya terbatas pada konsumen Denara Bali di Kota Denpasar, atau dapat juga mengganti lokasi penelitian yang tidak hanya terfokus pada suatu lokasi penelitian, sehingga memberikan suatu pandangan yang lebih dan mampu diimplementasikan secara umum.

\section{REFERENSI}

Ago, G., Suharno, Mintarti, S., \& Hariyadi, S. (2015). Effect Of Product Quality Perception, Trust, And Brand Image On Generic Drug Buying Decision And Consumer Satisfaction Of Hospital Patientsi In East Kalimantan. European Journal of Business and Management, 7(14), 50-69.

Angkie, Noviani Sari; Tanoto, S. R. (2019). Pengaruh Social Media Marketing Terhadap Brand Equity Pada Brand Fashion Zara, H\&M, Pull\&Bear, Dan Stradivarius Di Surabaya. Agora, 7(1), 6.

Anizir; Wahyuni, R. (2017). PENGARUH SOCIAL MEDIA MARKETING TERHADAP BRAND IMAGE PERGURUAN TINGGI SWASTA DI KOTA SERANG. Jurnal Sains Manajemen, 3(2), 0. https://doi.org/10.1017/CBO9781107415324.004

Ayuningtyas, A. S., Fauzi Dh, A., \& Nuralam, I. P. (2019). Pengaruh terpaan media sosial Instagram terhadap keputusan berkunjung dengan citra destinasi sebagai variabel mediasi Survey pada pengunjung Kampung Tridi (Tiga Dimensi) Malang. Jurnal Administrasi Bisnis, 68(1), 45-54.

Bramantya, Y. B., \& Jatra, M. (2016). Pengaruh Celebrity Endorser Dan Brand Image Terhadap Keputusan Pembelian Yamaha Jupiter Mx Di Kota Denpasar. E-Jurnal Manajemen Universitas Udayana, 5(3), 1745-1771.

Citra, T., \& Santoso, S. B. (2016). ANALISIS PENGARUH KUALITAS PRODUK DAN CITRA MEREK TERHADAP KEPUTUSAN PEMBELIAN CETAKAN CONTINUOUS FORMMELALUI KEPERCAYAAN MEREK (Studi pada Percetakan Jadi Jaya Group, Semarang). 13, 67-79.

Forum.Femaledaily.com. Thread: Body Scrub and Lulur Products, Page 233. (n.d.). Retrieved from https://forum.femaledaily.com/showthread.php?1426Body-Scrub-and-Lulur-Products/page233

Foster, B. (2017). Impact of Brand Image on Purchasing Decision on Mineral 
Water Product "Amidis" (Case Study on Bintang Trading Company). American Research Journal of Humanities and Social Sciences, 2(1), 1-11. https://doi.org/10.21694/2378-7031.16023

Ghozali, I. (2013). Aplikasi Analisis Multivariate dengan Program SPSS.

Semarang: Badan Penerbit Universitas Diponegoro.

Godey, B., Manthiou, A., Pederzoli, D., Rokka, J., Aiello, G., Donvito, R., \& Singh, R. (2016). Social media marketing efforts of luxury brands: Influence on brand equity and consumer behavior. Journal of Business Research, 69(12), 5833-5841. https://doi.org/10.1016/j.jbusres.2016.04.181

Gunelius, S. (2011). 30 Minute Social Media Marketing. United States: McGraw Hill.

Kompasiana.com. Offline Marketing vs Online Marketing. (n.d.). Retrieved from https://www.kompasiana.com/alihamzah/57641bd6a123bd840415484f/offlin e-marketing-vs-online-marketing

Kotler, Philip; Armstrong, G. (2008). Prinsip-Prinsip Pemasaran (12th ed.). Jakarta: Erlangga.

Kotler, Philip; Armstrong, G. (2012). Prinsip-Prinsip Pemasaran (12th ed.). Jakarta: Erlangga.

Kotler, Philip; Keller, K. (2009). Manajemen Pemasaran (Jilid I) (Edisi ke 1). Jakarta: Erlangga.

Kotler, Philip; Keller, K. (2012). Manajemen Pemasaran (Edisi 12). Jakarta: Erlangga.

Kotler, Philip; Keller, K. (2016). Marketing Management (15th Editi). New Jersey: Perason Pretice Hall, Inc.

Lubiana, \& Fauzi, M. \& A. (2018). Pengaruh Social Media Marketing Terhadap Keputusan Pembelian ( Survei Online pada Mahasiswa Sarjana Jurusan Ilmu Administrasi Bisnis Angkatan 2014 / 2015 Fakultas Ilmu Administrasi Universitas Brawijaya yang Membeli Starbucks. Jurnal Administrasi Bisnis (JAB), 1(1), 190-199.

Lubis, D. I. D., \& Hidayat, R. (2017). Pengaruh Citra Merek dan Harga terhadap Keputusan Pembelian pada Sekolah Tinggi Ilmu Manajemen Sukma Medan. Jurnal Ilman, 5(1), 15-24.

Lubis, I. B. H., \& Wibowo, A. (2016). Pengaruh Citra Merek, Media Iklan Instagram , Pembelian Produk Vans ( Studi Kasus Pada Followers Twitter @ VHeadID ). Jurnal Manajemen Bisnis Indonesia, 05(4), 388-401.

Morissan. (2014). Metode Penelitian Survey. Jakarta: Kencana Prenada Media Group. 
Pamungkas, B. A., \& Zuhroh, S. (2016). Pengaruh Promosi di Media Sosial dan Word of Mouth Terhadap Keputusan Pembelian (Studi Kasus Pada Kedai Bontacos, Jombang). Jurnal Komunikasi, X(2), 145-160.

Ridho, M. R. (2013). Pengaruh E-Marketing Terhadap Citra Merek Nay@ Dam Pada Pt Kreasi Putra Serayu. E-Journal Up Batam, 1(1), 57-76. Retrieved from http://www.academia.edu/download/38266772/11_Jurnal_Rasid_Emarketing _Citra_Merk_Nay_dam.pdf

Samad, Abdul ; Wibowo, I. (2016). Pengaruh Produk Dan Citra Merek Terhadap Keputusan Pembelian Sepatu Olahraga Merek Specs Di Kota Bekasi. Jurnal Manajemen Bisnis Krisnadwipayana, 4(3).

https://doi.org/10.35137/jmbk.v4i3.60

Saputri, Marheni Eka; Pranata, T. R. (2014). Pengaruh Brand Image Terhadap Kesetiaan Pengguna Smartphone Iphone. Jurnal Sosioteknologi, 13(3), 193201. https://doi.org/10.5614/sostek.itbj.2014.13.3.3

Solis, B. (2010). Engage: The Complete Guide for Brands and Businesses to Build, Cultivate, and Measure Success in the New Web. New Jersey: Wiley.

Suryonaningsih, Emi; Paramita, Patricia Dhiana; Hasiholan, L. B. (2016). Effect of Price and Image Brand on Consumer Satisfaction. Journal of Management, 2(2).

Tanzila; Sohail, Ali Akbar; Tanveer, N. (2015). Buying Behavior of Smartphone among University Students in Pakistan. The International Journal of Business and Management, 3(1), 34-40.

Tjiptono, Fandy; Chandra, G. (2005). Service, Quality, \& Satisfaction. Yogyakarta: Andi.

Tjiptono, Fandy; Chandra, G. (2011). Strategi Pemasaran (Edisi 3). Yogyakarta: ANDI.

Weiberg, T. (2009). The New Community Rules : Marketing on the Social Web. California: O’ Reilly.

Wijaya, S. B. (2013). Dimensions of Brand Image: A Conceptual Review from the Perspective of Brand Communication. European Journal of Business and Management, 5(31), 55-65. https://doi.org/10.13140/ejbm.2013.55.65

Zanjabila, R., \& Hidayat, R. (2017). ANALISIS PENGARUH SOCIAL MEDIA MARKETING TERHADAP KEPUTUSAN PEMBELIAN BANDUNG TECHNO PARK ( STUDI PADA PELANGGAN BANDUNG TECHNO PARK 2017 ) ANALYSIS OF SOCIAL MEDIA MARKETING ON PURCHASING DECISIONS OF BANDUNG TECHNO PARK ( STUDY ON BANDUNG TECHNO PARK CU. 3(2), 368-375. 
Kompyang Gede Sathya Narayana, Peran Brand Image....

Zimmerman, Dan; Doug, S. (2010). Social media marketing All in One for Dummies. New Jersey: Wiley Publishing. 